\title{
LEVOFLOXACIN VERSUS CEFIXIME AS AN EMPIRIC TREATMENT IN ACUTE BACTERIAL PROSTATITIS
}

\author{
CĂTĂLIN PRICOP ${ }^{1,2 \#, ~ D R A G O S ~ P U I A ~}{ }^{1,2}$, DANIEL ANDONE $^{2}$, SILVIU LATCUU $^{3}$, GEORGE $^{2}$ \\ DANIEL RĂDĂVOI ${ }^{5 *}$, IOAN CORDOȘ ${ }^{5 *}$, VIOREL JINGA $^{5}$, TUDOR PROCA ${ }^{5}$, ALIN CUMPĂNAȘ ${ }^{3}$ \\ 1 "Grigore T. Popa" University of Medicine and Pharmacy, Faculty of Medicine, Discipline of Urology, 16 Universităţii \\ Street, 700115, Iaşi, Romania \\ 2 "Dr. C.I. Parhon" Clinical Hospital, Clinic of Urology, 50 Carol I Boulevard, 700503, Iași, Romania \\ 3 "Victor Babeș" University of Medicine and Pharmacy, Faculty of Medicine, Discipline of Urology, Timișoara, Romania \\ 4 "Grigore T. Popa" University of Medicine and Pharmacy, Faculty of Medicine, Department of Mother and Child Medicine, \\ 16 Universitătii Street, Iași, Romania \\ 5 "Carol Davila" University of Medicine and Pharmacy, Faculty of Medicine, Discipline of Urology, 37 Dionisie Lupu Street, \\ Bucharest, Romania
}

*corresponding author: radadaniel@yahoo.com

${ }^{\#}$ Authors with equal contribution.

Manuscript received: April 2021

\begin{abstract}
Acute bacterial prostatitis (ABP) is a clinical condition frequently encountered in clinical practice, but there is a lack of consensus for the diagnosis, investigations, and treatment for this pathology. We have enrolled patients diagnosed with acute prostatitis in three academic urological centres between 2019 - 2020 and followed-up prospectively their evolution under two different frequently used antibiotics-fluoroquinolones and cephalosporins, both combined or not with alpha-blockers. All patients received standard start-up treatment. A total of 154 patients were included. Both groups had similar side effects rates ranging from $8.97 \%$ to $11.84 \%$. Both groups had similar positive urine culture $15.38 \%$ for group A, respectively $14.47 \%$ for group B. Although it is an ongoing study, we can confirm that fluoroquinolones and cephalosporins, with or without alpha-blocker, are as effective and tolerated in enhancing empirical treatment initiated at admission for patients with acute bacterial prostatitis.
\end{abstract}

\section{Rezumat}

Prostatita bacteriană acută (ABP) este o afecțiune clinică întâlnită frecvent în practică, dar există o lipsă de consens pentru standardizarea diagnosticului, a investigațiilor și pentru stabilirea tratamentului. În acest studiu prospectiv au fost înrolați pacienți diagnosticați cu prostatită acută din trei centre urologice academice în perioada 2019 - 2020 și s-a urmărit evoluția sub tratamentul cu două antibiotice utilizate frecvent - fluorochinolone (grupul A) și cefalosporine (grupul B), ambele combinate sau nu cu alfa-blocante. Toți pacienții au primit tratament standard la internare. Au fost incluși un total de 154 de pacienți. Ambele grupuri au avut rate de efecte secundare similare, variind între 8,97\% și 11,84\%. Ambele grupuri au avut frecvența uroculturilor pozitive similară: 15,38\% pentru grupul A, respectiv 14,47\% pentru grupul B. Deși studiul este încă în desfăşurare, putem confirma că fluorochinolonele și cefalosporinele, cu sau fără alfa-blocant, sunt la fel de eficiente şi tolerate în îmbunătățirea tratamentului empiric inițiat la internare la pacienții cu prostatită acută bacteriană.

Keywords: acute bacterial prostatitis, side effects, fluoroquinolone, cephalosporins

\section{Introduction}

Acute bacterial prostatitis (ABP) is a clinical condition frequently encountered in clinical practice. Even so, currently, there is a lack of consensus for the diagnosis, investigations and treatments for acute bacterial prostatitis. According to the EAU guidelines, eventhough less than $10 \%$ of the cases have proven bacterial infection, high doses of bactericidal antimicrobials, such as a third-generation cephalosporin or fluoroquinolones, are recommended [1].

The downside of giving an empirical treatment with high doses of antibiotics is the risk of developing antibiotic resistance and also, to create the premises to induce unwanted adverse events [2]. With the rise of bacterial antibiotic resistance in the population and the economic strain antibiotherapy upon the health system, choosing the right antibiotic for empirical treatment is essential [3].

The aim of the study was to evaluate the effectiveness of fluoroquinolones $v s$. third-generation cephalosporin therapy regimens and to provide a better picture of the two EAU recommended antibiotic agents for the treatment of $\mathrm{ABP}$.

\section{Materials and Methods}

We have enrolled patients diagnosed with acute prostatitis in three academicals urological centres between 2019 and 2020; the exclusion criteria were: 
previous treatment with fluoroquinolones or cephalosporins, previous cystoscopy or prostatic biopsy, ultrasound changes of the urinary tract (hydronephrosis, kidney/bladder stones) and the presence of an indwelling catheter. We named this type of infection as "naïve" acute bacterial prostatitis. The patients diagnosed with acute prostatitis were hospitalized and received empiric antibiotic treatment (gentamicin $240 \mathrm{mg} /$ day plus ciprofloxacin $800 \mathrm{mg} /$ day). After three days of hospitalization, the patients were discharged. Since day 4 , the patients were randomly included into two groups and received home treatment with an oral antibiotic plus an alpha-blocker (tamsulosin $0.4 \mathrm{mg}$ once daily) for 21 days. Patients from the first group (A) received levofloxacin $500 \mathrm{mg}$ once daily and those from the second group (B) received cefixime $400 \mathrm{mg}$ once daily. All patients received non-steroidal anti-inflammatory drugs (celecoxib, $200 \mathrm{mg}$ once daily) for 14 days. We have chosen the two antibiotics because the administration pathway is identical and it is given once daily.

Creatinine levels were followed-up to see if there was any renal impairment caused by acute bacterial prostatitis and also to observe if there were any side effects caused by the antibiotics and which one had higher nephrotoxicity.

We excluded patients with previous treatment with fluoroquinolones or cephalosporins, ultrasound changes of the urinary tract, and those who had urinary indwelling catheters. At the follow-up visit, performed between days 30 and 35, after the start of the antibiotic therapy, we evaluated the clinical status, paraclinical parameters and an abdominal ultrasound was achieved. We decided not to follow PSA levels due to the high variability and unknown status before the prostatitis event.

The biochemical parameters were analysed with ARCHITECT c4000 Clinical Chemistry Analyzer (Abbott Laboratories) while for the WBC a XN-450 analyser (Sysmex Europe $\mathrm{GmbH}$ ) was used. For the urine cultures, Cystine Lactose Electrolyte Deficient (CLED) Agar and blood-agar mediums were used to culture the bacteria. We also calculated the Multiple Antibiotic Resistance (MAR) index as the ratio between the number of antibiotics that a bacteria is resistant to and the total number of antibiotics the organism is exposed to.

All the study participants sign an informed consent for the inclusion in the study. The study was conducted in accordance with the Declaration of Helsinki, and the protocol was approved by the Local Ethics Committee. Statistical analysis

The statistical analysis was performed using the tStudent, ANOVA and Chi-square tests. We have considered statistically significant a p-value of $<0.05$. The SPSS.16 software was used.

\section{Results and Discussion}

A total of 154 patients were included, aged 19 to 73 years old, mean age 44.25 years. Patients' clinical, demographics and biochemical parameters are showed in the Table I.

Table I

Demographics and biochemical findings

\begin{tabular}{|l|c|c|}
\hline & group A & group B \\
\hline No. patients & 78 & 76 \\
\hline Environment Rural/Urban* & $26 / 52$ & $22 / 54$ \\
\hline Mean age (years)* & $45.37 \pm 8.4$ & $42.96 \pm 7.16$ \\
\hline Initial mean WBC* & $15330.27 \pm 3856.16$ & $16679.54 \pm 6287.58$ \\
\hline Initial mean CRP (mg/dL)* & $127.81 \pm 98.01$ & $125.67 \pm 95.10$ \\
\hline Initial mean serum creatinine (mg/dL)* & $1.1475 \pm 0.43$ & $1.09 \pm 0.32$ \\
\hline Follow-up mean WBC* & $7338.06 \pm 2186.33$ & $7213.75 \pm 2101.45$ \\
\hline Follow-up mean serum creatinine (mg/dL)* & $1.079 \pm 0.42$ & $1.014 \pm 0.29$ \\
\hline
\end{tabular}

$* p>0.05$

treatment values were significantly reduced and

Looking at the blood analysis levels at the time of hospital admission, we have seen that both groups were consistently similar regarding their blood analysis levels. White blood cell count showed an initial mean of 15330.27 in Group A and 16679.54 in group B with no significant statistical difference $\mathrm{p}=0.515$. At the follow-up assessment, the WBC level was restored to normal values (7338.06 for group A, respectively 7213.75 for group B).

As an inflammation follow-up marker, we also used CRP which had a similar evolution. The values obtained before the treatment were similar in the two groups: A $127.81 \mathrm{mg} / \mathrm{dL} v s$. B $125.67 \mathrm{mg} / \mathrm{dL}$. The after- maintained a descending pattern.

At the follow-up visit, $8.97 \%$ of 78 patients in group A reported side effects compared with $11.84 \%$ in group $\mathrm{B}$, with no statistical difference between groups $(p=0.78)$. Seven patients from group A presented 11 adverse drug reactions (ADR), respectively nine patients from group B developed 12 ADR. Patients under levofloxacin treatment developed mainly gastrointestinal reactions, followed by dermatological, musculoskeletal and other reactions (cardiovascular, central nervous system). The given dose of $500 \mathrm{mg}$ 
levofloxacin was well tolerated in the majority of the patients (Table II).

Group B, under cephalosporins treatment, developed similar adverse side effects, but with different distribution, have been developing gastrointestinal, dermatological and central nervous system ADR, except for musculoskeletal reactions.

Regarding the control urine culture, 12 (15.38\%) patients from group A had positive urine culture (Escherichia coli 7, Enterococcus faecalis 3, Proteus mirabilis 1, Pseudomonas aeruginosa 1), while in group B, $11(14.47 \%)$ patients had positive urine culture (Escherichia coli 7, Enterococcus faecalis 1, Enterobacter 2, Proteus mirabilis 1), the difference being not significant ( $\mathrm{p}>0.05) .23$ positive urocultures out of 154 patients with acute bacterial prostatitis represents an average of $14.95 \%$. This percentage is significantly higher than the average European incidence of $10 \%$ positive cultures $[1,4]$.

Table II

Adverse drug reactions to levofloxacin and cefixime

\begin{tabular}{|c|c|c|c|c|c|}
\hline$*$ & Gastrointestinal & Musculoskeletal & Dermatological & Cardiovascular & Other \\
\hline Group A (7 patients 11 ADR) & $36.3 \%(4)$ & $18.1 \%(2)$ & $18.1 \%(2)$ & $9.09 \%(1)$ & $18.1 \%(2)$ \\
\hline Group B (9 patients 12 ADR) & $50 \%(6)$ & 0 & $16.66 \%(2)$ & $8.33 \%(1)$ & $25 \%(3)$ \\
\hline
\end{tabular}

* percentage out of ADR/drug

When it comes to antibiotic resistance, we decided to follow-up with the most representative bacteria, Escherichia coli. Local resistance to quinolones is one important issue and cephalosporins are also close to follow the same pattern. Even though the positive urocultures might be reduced in this study, the local resistance was confirmed. Positive urocultures in acute bacterial prostatitis is a rare finding (Figures 1-4).

Also, we noticed relapse that required readmission in 5 patients (2 from group A and 3 from group B),

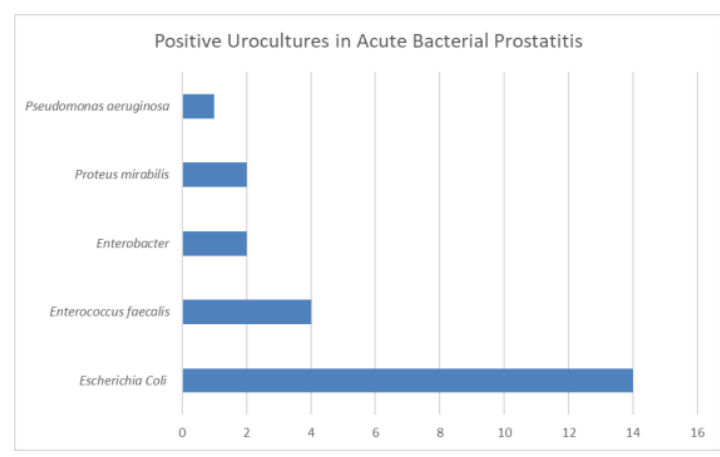

Figure 1.

Microorganism findings in positive urocultures from both groups

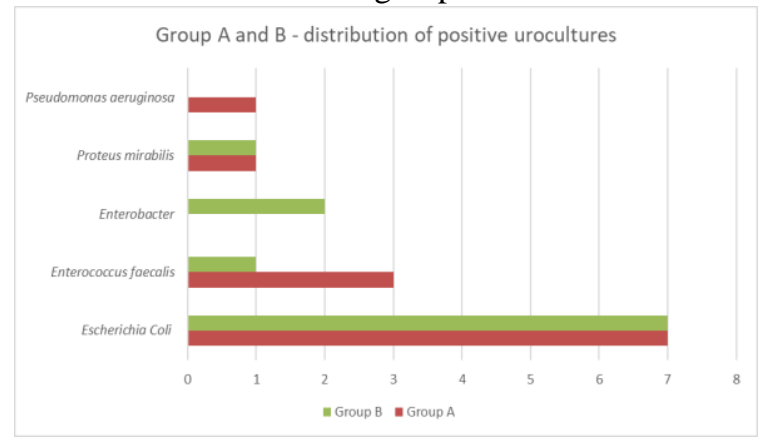

Figure 3.

Distribution of positive urine cultures by analysed group the difference being not significant from this point of view $(\mathrm{p}>0.05)$.

Three patients experienced acute urinary retention during antibiotic treatment, two of them regaining the ability to urinate after the first attempt of removing the indwelling catheter. The other patient (age 59) was submitted to transurethral resection of the prostate after four months since he did not obtain physiologic micturition after several catheter removals.

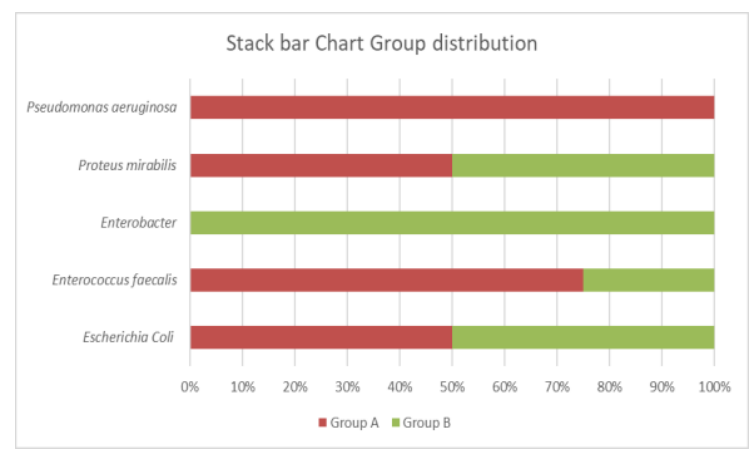

Figure 2.

Stack bar distribution showing the percentage of positive cultures/group

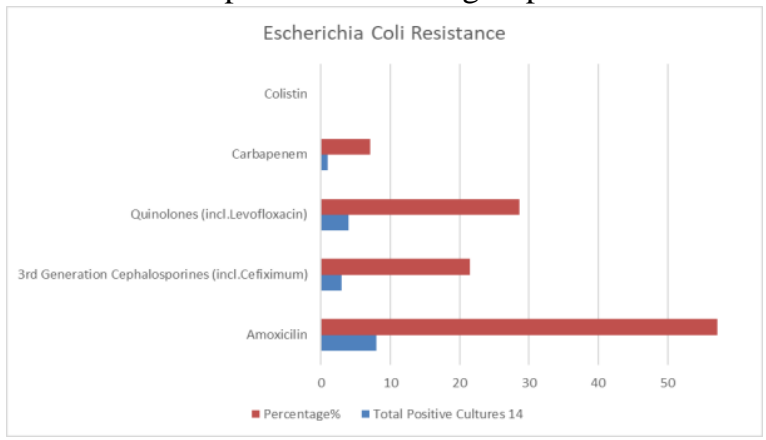

Figure 4.

Escherichia coli resistance 
Although prostatitis is a common diagnosis, according to EAU guidelines, less than $10 \%$ of cases have proven bacterial infection, but according to some other authors like Neal et al. the percentage is closer to $5 \%[1,4]$. Similar aspects were confirmed by our study showing increased uroculture positivity among the patients included in both groups. This highlights and confirms that the antibiotic administered should be based on empiric guidelines since it is very difficult to identify the pathogenic microorganism. Disregarding the incidence, giving to patients a correct treatment is very important to avoid complications and/or progression of the disease. Despite the advancement of treatment with antibiotics and the fact that most patients with ABP recover without having complications, Yoon et al. reported a progression rate of $\mathrm{ABP}$ to chronic bacterial prostatitis between $4.2 \%$ and $8.1 \%$, while according to Millán-Rodríguez et al. the recurrence rate for $\mathrm{ABP}$ is about $13 \%[5,6]$.

ABP is a condition difficult to treat as few antimicrobials reach therapeutic concentrations in the prostate. This is one of the reasons why the duration of some therapeutic schemes can last up to 6 weeks. Most patients can be treated with outpatient antibiotics, according to Coker et al. Criteria for hospitalization are failed outpatient management, inability to tolerate oral intake, resistance risk factors, recent fluoroquinolone use, recent transurethral, or trans-rectal prostatic manipulation, systemically ill or septicaemia, urinary retention [7].

Currently, there is a lack of agreed-upon guide-lines for the treatment of male urinary tract infections (UTI), in particular concerning ABP. While Gilbert et al. recommends treating patients initially for Neisseria gonorrhoeae and Chlamydia trachomatis in young adults, others like Naber et al., recommend treatment only for Enterobacteriaceae [8, 9]. There is also a great heterogeneity regarding the antibiotic management of the disease. According to Lipsky et $a l$., the $\beta$-lactams have limited penetration into the prostate while tetracyclines achieve sufficient concentrations in the prostate, but extensive resistance limits their use [10]. Other agents like trimethoprimsulfamethoxazole (TMP-SMX) have been used successful to treat bacterial prostatitis, due to sufficient prostate penetration, but resistance also has limited its use. After demonstrating clinical efficacy in the treatment of acute uncomplicated cystitis and promising in vitro activity against ESBL-producing MDR E. coli, Zhanel et al. reviewed the use of oral fosfomycin for the treatment of bacterial prostatitis [11]. According to the authors, oral fosfomycin's clinical cure rates in the treatment of bacterial prostatitis caused by antimicrobial-resistant $E$. coli ranges from 50 to $77 \%$ with microbiological eradication rates of > $50 \%$. The most effective regimen of oral fosfomycin tromethamine is $3 \mathrm{~g} \cdot$ per $24 \mathrm{~h}$ for one week followed by $3 \mathrm{~g}$ per $48 \mathrm{~h}$ for a total treatment duration of 6 - 12 weeks.

Currently, EAU guidelines recommend parenteral administration of high doses of bactericidal antimicrobials, such as broad-spectrum penicillin's, a third-generation cephalosporin, or fluoroquinolones, with the mention that for initial therapy, any of these antimicrobials may be combined with an aminoglycoside. Also, if there is residual urine, alphareceptor blockers should be used. Alpha-blockers were included in the treatment scheme of our patients even if we excluded patients with ultrasound changes of the urinary tract (significant postvoid residual urine volume).

Combination therapy of alpha-blocker and fluoroquinolones could be more efficient than monotherapy. In an animal model, Qin et al. showed that in the prostatic tissues, but not in plasma or hepatic and kidney tissues, tamsulosin increases the maximum concentration, prolongs the halftime, and decreases the clearance rate of levofloxacin [12].

In humans, on that other hand, according to Nickel, alpha-blocker therapy has been advocated, with various levels of evidence, as a treatment modality for all categories of the prostatitis syndromes, but there are no data, only unsubstantiated anecdotal experience, to support the use of $\alpha$-blockers in acute bacterial prostatitis [13].

Because they have a relatively high distribution into the prostate and a generally good safety profile and antibacterial activity against Gram-negative pathogens including $P$. aeruginosa and $C$. trachomatis, fluoroquinolones are recommended as first-line agents in the empirical treatment, despite the high resistance rates of uropathogens [1].

Unfortunately, prolonged treatment with fluoroquinolones may have many side effects. According to Roberts, the most frequent adverse effects occur in the GI tract (3 - 15\% of patients) as anorexia, nausea, vomiting, and abdominal discomfort. Mild diarrhoea is usually not significant, but fluoroquinolones can cause Clostridium difficile-associated diarrhoea. Also, they can influence the central nervous system (headache, dizziness, and insomnia), cardiovascular system (QT prolongation and arrhythmias), and muscular system (tendinopathy and tendon rupture) [14]. In a group of 471 patients treated for chronic bacterial prostatitis with fluoroquinolones, Zhang et al. reported overall rates of adverse events and treatment-related adverse events of $3.33 \%$ in patients who received levofloxacin and $6.03 \%$ in those with ciprofloxacin [15]. Some other rare reactions to antibiotics are rashes, but patients with low urinary tract symptoms, especially the stocking symptoms, often receive overactive bladder syndrome diagnosis and treatment. Anticholinergic treatment can also cause rashes in up to $3.06 \%$ [16] and by the time the patients receive antibiotic treatment for the correct 
diagnosis adverse effects of antibiotics might overlap with the previous medication. For this reason, we decided not to follow rare adverse effects in our study. In addition, some authors might recommend a dose of $750 \mathrm{mg}$ which comes with higher rates of ADR. Another variability factor between different research sites is the period of administration ranging from 2 weeks to 4 weeks.

Although, it is considered that cephalosporins are not distributed well into the prostate, according to EAU guidelines, clinicians should consider local drugresistance patterns when choosing antibiotics [1]. More than that, according to Nagy et al., fluoroquinolone resistance is a growing problem that generally requires intervention with a $3^{\text {rd }}$-generation cephalosporin (e.g. ceftazidime or ceftriaxone) or a carbapenem (e.g. imipenem or ertapenem) [17]. The authors suggest an empirical treatment with a broad-spectrum betalactam drug - either penicillin (e.g. piperacillintazobactam) or a cephalosporin (e.g. cefotaxime or ceftazidime), for patients with $\mathrm{ABP}$ who are severely ill or who have recently received antibiotic therapy. Our study has some limitations: we treated patients empirically and the evolution of the patients (beforeafter) was only based on blood analysis without subjective symptom scores or quality of life. To identify the pathogen and the antibiotic spectrum, urine testing before and after prostatic massage (also known as the Meares-Stamey 2-glass or 4-glass test) is needed. However, such investigations are not recommended in patients with suspected acute bacterial prostatitis because prostatic massage increases the risk of bacteraemia, and subsequently, sepsis.

Another aspect that should be noted is the recent update in fluoroquinolone use. Having good pharmacokinetics, broad-spectrum, and being easy to dose, this class of antibiotics occupies the third position among the most commonly used [18]. Even though they have numerous advantages, they also have important disadvantages which have been more visible in recent statistics. Starting with the second half of 2018 the Food and Drug Administration showed important arguments regarding the risks of serious side effects of fluoroquinolones which outweigh the benefits of this antibiotic class in treating mild infections [19]. Starting from late 2019, EAU changed the policy of using fluoroquinolones and during the beginning of 2020 national letters and informative programs have started to announce practitioners to reconsider the use of this class. Even though there is a high resistance rate for both quinolones and cephalosporins in Romania, cephalosporins still have a slightly lower resistance rate [20].

Another important aspect is the high antimicrobial resistance to fluoroquinolones of the most frequent bacteria in patients with acute bacterial prostatitis, Escherichia coli. In Romania, E. coli has a fluoroquinolone resistance of $29.55 \%$. Antibiotical stewardship programs have been implemented in our country to fight against developing resistant bacteria by educating physicians to adapt, reduce, and change treatment. Another advantage of reducing the consumption of fluoroquinolones, except the consequent drop of selection resistant microbial strains, is also the decreasing risk of developing Clostridium difficile colitis in our patients [21]. The increased use of quinolones and cephalosporins is also confirmed in other departments such as gastroenterology making it mandatory to continue and develop antimicrobial stewardship programs [22].

Last, but not least, is the problem of treating Enterococcus faecalis in these patients. Due to the fact that it is uncertain the real true correspondence, because of the low rate of positive urine cultures in acute bacterial prostatitis, it is difficult to decide which treatment option the practitioner should follow. Even though we had only 4 cases of positive urine cultures in both groups, the average MAR index was 0.475 (MAR for each of the 4 cultures was $0.5,0.2$, $0.6,0.6$ ) with resistance to clindamycin, erythromycin, trimpethoprim-sulphamethoxazole, gentamicin. These patients were sensitive to either one or the other of the two antibiotics included in this study and proper treatment was given. However, it is well known that Enterococcus faecalis is highly resistant to cefuroxime and fluoroquinolones [22] and given the fact that less than $10 \%$ of acute bacterial prostatitis have positive urine cultures it is difficult for responsible physicians to make proper treatment choices.

\section{Conclusions}

Although it is an ongoing study, based on our data so far, we can say that fluoroquinolones and cephalosporins, with or without alpha-blocker, are as effective and tolerated in enhancing empirical treatment initiated at admission for patients with acute bacterial prostatitis. Fluoroquinolones are about to be less prescribed in the near future, but we can rely on other classes to treat acute bacterial prostatitis. Antimicrobial stewardship programs are necessary and shifting to less resistant classes is inevitable.

\section{Conflict of interest}

The authors declare no conflict of interest.

\section{References}

1. Bonkat $\mathrm{G}$, Bartoletti R, Bruyère $\mathrm{F}$, Cai $\mathrm{T}$, Geerlings SE, Köves B, Schubert S, Wagenlehner F, Mezei T, Pilatz A, Pradere B, Veeratterapillay R, EAU Guidelines on Urological Infections 2020, https://uroweb. org/.

2. Gajdács $\mathrm{M}$, Ábrók $\mathrm{M}$, Lázár A, Burián $\mathrm{K}$, Epidemiology and antibiotic resistance profile of 
bacterial uropathogens in male patients: a 10-year retrospective study, Farmacia, 2021; 69(3): 530-539.

3. Pricop C, Furtunescu LF, Radavoi GD, Jinga V, Cumpanas A, Anton-Paduraru DT, Miron A, Toma C, Puia D, Antibiotic prophylaxis in transurethral resections: What are the criteria that should be followed?. Farmacia, 2020; 68(6): 1021-1028

4. Neal DE Jr, Acute bacterial prostatitis. In: Nickel CJ, editor. Textbook of prostatitis. Oxford: Isis medical media; 1999; 115-121.

5. Yoon BI, Han DS, Ha US, Lee SJ, Sohn DW, Kim $\mathrm{HW}$, Han $\mathrm{CH}$, Cho YH. Clinical courses following acute bacterial prostatitis. Prostate Int., 2013; 1(2): 89-93.

6. Millán-Rodríguez F, Palou J, Bujons-Tur A, MusqueraFelip M, Sevilla-Cecilia C, Serrallach-Orejas M, Baez-Angles C, Villavicencio-Mavrich H, Acute bacterial prostatitis: two different sub-categories according to a previous manipulation of the lower urinary tract. World J Urol., 2006; 24(1): 45-50.

7. Coker TJ, Dierfeldt DM. Acute Bacterial Prostatitis: Diagnosis and Management. Am Fam Physician, 2016; 93(2): 114-120.

8. Gilbert DN, Mollelering RC, Sand M, The Sanford Guide to Antimicrobial Therapy. In: Park H, editor. The Sanford Guide to Antimicrobial Therapy. Antimicrobial Therapy Inc; 2005; 23-24

9. Naber KG, Bergman B, Bishop MC, BjerklundJohansen TE, Botto H, Lobel B, Jinenez Cruz F, Selvaggi FP, Urinary Tract Infection (UTI) Working Group of the Health Care Office (HCO) of the European Association of Urology (EAU). Eur Urol., 2001; 40(5): 576-588.

10. Lipsky BA, Byren I, Hoey CT, Treatment of bacterial prostatitis. Clin Infect Dis., 2010; 50(12): 1641-1652.

11. Zhanel GG, Zhanel MA, Karlowsky JA, Oral Fosfomycin for the Treatment of Acute and Chronic Bacterial Prostatitis Caused by Multidrug-Resistant Escherichia coli. Can J Infect Dis Med Microbiol., 2018; 2018: 1404813: 1-8.

12. Qin GD, Xiao MZ, Zhou YD, Yang J, He HX, He Y, Zeng Y, Tamsulosin alters levofloxacin pharmacokinetics in prostates derived from rats with acute bacterial prostatitis. Asian J Androl., 2013; 15(2): 254-260.
13. Nickel JC, Alpha-blockers for the treatment of prostatitis-like syndromes. Rev Urol.. 2006; 8(Suppl 4): S26-S34.

14. Roberts JR. Fluoroquinolone Side Effects Just Got Scarier. Emerg Med News, 2018; 40(10): 26-27.

15. Zhang ZC, Jin FS, Liu DM, Shen ZJ, Sun YH, Guo YL, Safety and efficacy of levofloxacin versus ciprofloxacin for the treatment of chronic bacterial prostatitis in Chinese patients. Asian J Androl., 2012; 14(6): 870-874.

16. Ancuceanu R, Dinu M, Furtunescu F, Boda D, An inventory of medicinal products causing skin rash: Clinical and regulatory lessons. Exp Ther Med., 2019; 18(6): 5061-5071.

17. Nagy V, Nagy V, Kubej D, Acute Bacterial Prostatitis in Humans: Current Microbiological Spectrum, Sensitivity to Antibiotics and Clinical Findings. Urol Int., 2012; 89: 445-450.

18. Kabbani S, Hersh AL, Shapiro DJ, Fleming-Dutra KE, Pavia AT, Hicks LA, Opportunities to improve fluoroquinolone prescribing in the United States for adult ambulatory care visits. Clin Infect Dis., 2018; 67: 134-136.

19. US Food and Drug Administration. FDA updates warnings for fluoroquinolone antibiotics on risks of mental health and low blood sugar adverse reactions. News release, 2018, https://www.fda.gov.

20. Neag MA, Bocsan IC, Vesa S, Gosa D, Catineanu A, Nagy G, Mircea PA, Buzoianu AD, The inadequate use of antibiotics in a gastroenterology department. Farmacia, 2019; 67(6): 1066-1070.

21. Florescu SA, Nedelcu NI, Calistru PI, Petruc F, Ceausu E, Significant decreasing of the systemic antibiotics consumption associated with antimicrobial stewardship intervention conducted in infectious diseases university hospital from Eastern Europe. Farmacia, 2017; 65(3): 356-359.

22. Popescu GA, Serban A, Pistol A, Antibiotic Consumption, Microbial Resistance and Nosocomial Infections in Romania, www.cnscbt.ro, (available in Romanian). 